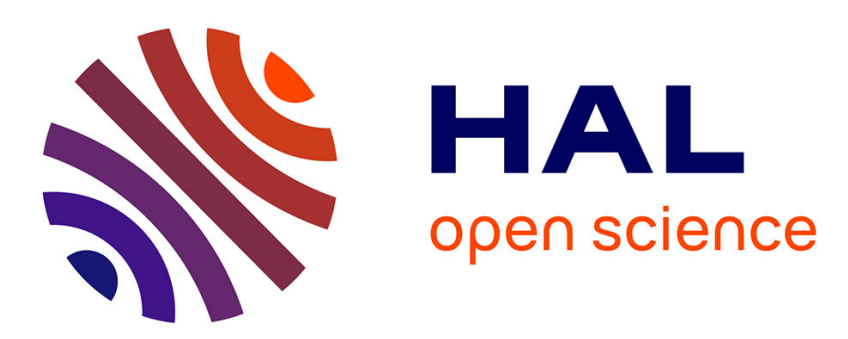

\title{
Comparative distributions of dicarboxylic acids and related polar compounds in snow, rain and aerosols from urban atmosphere
}

Richard Sempere, Kawamura Kimitaka

\section{- To cite this version:}

Richard Sempere, Kawamura Kimitaka. Comparative distributions of dicarboxylic acids and related polar compounds in snow, rain and aerosols from urban atmosphere. Atmospheric Environment, 1994, 28, pp.449-459. 10.1016/1352-2310(94)90123-6 . hal-01171592

\section{HAL Id: hal-01171592 \\ https://hal.science/hal-01171592}

Submitted on 25 Feb 2019

HAL is a multi-disciplinary open access archive for the deposit and dissemination of scientific research documents, whether they are published or not. The documents may come from teaching and research institutions in France or abroad, or from public or private research centers.
L'archive ouverte pluridisciplinaire HAL, est destinée au dépôt et à la diffusion de documents scientifiques de niveau recherche, publiés ou non, émanant des établissements d'enseignement et de recherche français ou étrangers, des laboratoires publics ou privés. 


\title{
COMPARATIVE DISTRIBUTIONS OF DICARBOXYLIC ACIDS AND RELATED POLAR COMPOUNDS IN SNOW, RAIN AND AEROSOLS FROM URBAN ATMOSPHERE
}

\author{
RichaRd SEMPÉrÉ* and Kimitaka Kawamura $\dagger$ \\ Department of Chemistry, Faculty of Science, Tokyo Metropolitan University, Minami-Ohsawa, Hachioji, \\ Tokyo 192-03, Japan
}

(First received 24 March 1993 and in final form 11 August 1993)

\begin{abstract}
Nine wet precipitation (snow, sleet and rain) and four aerosol samples, collected from Tokyo, were studied for the molecular distributions of dicarboxylic acids and related polar compounds (ketoacids and dicarbonyls) by a capillary gas chromatography (GC) and GC-mass spectrometry. Wet samples were also analysed for dissolved organic carbon (DOC), whereas aerosol samples were studied for total carbon, total nitrogen and water soluble organic carbon. A homologous series of dicarboxylic acids $\left(C_{2}-C_{9}\right)$ were detected in both wet precipitation (12-540 $\left.\mu \mathrm{g} \ell^{-1}\right)$ and aerosol $\left(1.1-3.0 \mu \mathrm{g} \mathrm{m}^{-3}\right)$ samples. Although oxalic acid $\left(C_{2}\right)$ was generally the dominant diacid species followed by either malonic, succinic or phthalic acid in the samples studied, its relative abundance in total diacids was different between the wet precipitation (34 $\pm 8 \%)$ and aerosol $(51 \pm 5 \%)$ samples. These results suggest that oxalic acid is more enriched at near-ground level than upper levels of the troposphere. Time series of precipitation samples showed that diacid carbon concentration normalized by DOC decreased as a function of time during precipitation events. These results suggest that diacids, which exist as particles, are more efficiently scavenged from the atmosphere than other water soluble organic compounds.
\end{abstract}

Key word index: Diacids, ketoacids, dicarbonyls, snow, rain, aerosols, DOC, TOC, oxalic acid.

\section{INTRODUCTION}

Low molecular weight (LMW) dicarboxylic acids have been detected in aerosol samples from continental (Schuetzle et al., 1975; Cronn et al., 1977; Grosjean et al., 1978; Yokouchi and Ambe, 1986; Kawamura and Kaplan, 1987; Satsumabayashi et al., 1989, 1990 ) and remote marine (Kawamura and Gagosian, 1987; Kawamura and Usukura, 1993) atmosphere. Recent studies on molecular distribution of dicarboxylic acids generally showed the predominance of oxalic acid $\left(\mathrm{C}_{2}\right)$, followed by malonic acid $\left(\mathrm{C}_{3}\right)$ or succinic acid $\left(\mathrm{C}_{4}\right)$ in the aerosols (Kawamura and Ikushima, 1993). Their concentrations are generally higher in the summer. These dicarboxylic acids are derived from primary emissions from motor exhausts (Kawamura and Kaplan, 1987) and from secondary atmospheric reactions of anthropogenic hydrocarbons such as cyclic olefins (Grosjean et al., 1978; Grosjean and Friedlander, 1980; Hatakeyama et al., 1985) and biogenic unsaturated fatty acids (Yokouchi and Ambe, 1986; Kawamura and Gagosian, 1987). Although direct precursors have not been clearly identified, photochemical oxidations of aromatic hydrocarbons such as benzene and toluene, as well as malonic, succinic and maleic acids, have been

* Present address: Campus de Luminy, C.N.R.S. Case 907 70 Route Leon Lachamps, 13288 Marseille Cedex 9, France. †To whom all correspondence should be addressed. considered to result in oxalic acid (Kawamura and Ikushima, 1993).

Because dicarboxylic acids are very water soluble and mostly present as particles, they may be involved with a cloud condensation process and effectively removed from the atmosphere by in-cloud and belowcloud scavenging processes. Previous studies showed that diacids are abundantly present in rainwater samples (Norton et al., 1983; Likens et al.,1983: Kawamura et al., 1985). However, only few studies were conducted to clarify the diacid distributions on a molecular level in wet precipitations and there is no data available for urban snow, although snow and ice core samples from Greenland were studied for diacids (Kawamura and Yasui, 1991).

In the present study, we collected snow and rain samples in the urban atmosphere of Tokyo in time series and analysed for the molecular distributions of diacids and related polar compounds such as ketoacids and dicarbonyls. Wet precipitation samples were also analysed for total (TOC) and dissolved organic carbon (DOC). Aerosol samples collected at the same location, were studied for the diacids and related compounds, total carbon (TC) and nitrogen (TN), and water soluble organic carbon (WSOC). Here, we compare the distributions of dicarboxylic acids, ketocarboxylic acids and dicarbonyls between wet precipitations and aerosols and discuss the wet scavenging processes of polar organic compounds from the atmosphere. 


\section{EXPERIMENTAL}

\section{Collection of snow, rain and aerosol samples}

Nine precipitation samples were collected in winter and summer seasons of 1992 during one snow (18 March) and two rain events (rain I: 30 June, rain II: 1 August) at the rooftop of Tokyo Metropolitan University, Faculty of Science Building (ca. $\mathbf{4 0} \mathrm{m}$ above the ground level). The University campus is located at ca. $30 \mathrm{~km}$ west of central Tokyo. Rainwater samples were collected in a pre-cleaned brown glass bottle using a stainless steel rain collector with a cross section of $2800 \mathrm{~cm}^{2}$. Snow $/ \mathrm{sleet}$ samples were collected by the same collector. After sampling, a bactericide $\left(\mathrm{HgCl}_{2}\right)$ was added to the melted snow and rainwater samples, which were stored in a brown glass bottle with a Teflon-lined cap at $4^{\circ} \mathrm{C}$ prior to analysis. Rainwater samples were protected from biodegradation with $\mathrm{HgCl}_{2}$ during sample collection.

Aerosol samples were collected in the winter and summer of 1992 with a pre-combusted $\left(500^{\circ} \mathrm{C}\right)$ Pallflex quartz fiber filter $(20 \times 25 \mathrm{~cm})$ using a high-volume air sampler (Shibata HVC1000) at a rooftop of the Faculty of Science Building Four aerosol samples were used in this study. Total aeroso mass was determined by weighing the filter before and after sample collection.

Determination of dicarboxylic acids and related compounds by $G C$ and $G C-M S$

Dicarboxylic acids, ketoacids and dicarbonyls were measured by the method elaborated for liquid samples (Kawamura and Yasui, 1991). Wet samples $(100-150 \mathrm{ml})$ were concentrated by a rotary evaporator under a vacuum and dried in a nitrogen stream. The dried samples were then reacted with $14 \%$ borontrifluoride in $n$-butanol $(0.3 \mathrm{ml})$ to derive carboxyl and aldehyde groups to the butyl esters and dibutoxy acetals, respectively. The derivatives of dicarboxylic acids, ketoacids and dicarbonyls were extracted with $n$ hexane $(5 \mathrm{ml})$ in the presence of an organic free pure water $(3 \mathrm{ml})$ and acetonitrile $(0.3 \mathrm{ml})$, and the extracts were washed with the pure water $(3 \mathrm{ml} \times 2)$. The derivatives were concentrated to $50 \mu$ and determined by a Hewlett Packard (HP 5890) gas chromatograph (GC) equipped with a split/splitless injector, a HP-5 fused silica capillary column $(0.32 \mathrm{~mm}$ i.d. $\times 25 \mathrm{~m} \times 0.52 \mu \mathrm{m})$, and an FID detector. Identification of the derivatives were performed by a comparison of GC retention times and mass spectra with those of authentic standards. Identification of the compounds were confirmed by a GC-mass spectrometer system (Finnigan-MAT ITS-40).

Recoveries of diacids in the analytical procedure were $70 \%$ (oxalic), 77\% (malonic), 86\% (succinic) and 90\% (adipic). Procedural blanks showed small peaks of oxalic, pyruvic and phthalic acid derivatives in the GC chromatogram; however, they presented less than 1,2 and $4 \%$ of actual samples, respectively. Analytical errors in the determination of diacids were within $5.5 \%$ for dicarboxylic acids, $15 \%$ for ketoacids, $8 \%$ for glyoxal and $26 \%$ for methylglyoxal based on duplicate analysis of the rain I sample. The concentrations of the acids presented here are corrected for the procedural blanks. Although glyoxylic acid has been suggested to be partly oxidized to oxalic acid, possible overestimation is less than $3 \%$ of oxalic acid concentrations (Kawamura et al., 1985), which is within the analytical error of this procedure.

Aerosol samples were analysed for diacids by the method of Kawamura and Ikushima (1993). A part of the aerosol filter sample was cut into pieces and extracted with pure water (organic free) under a sonication to separate water soluble dicarboxylic acids and related polar compounds. The organic free water was prepared by boiling Milli $Q$ water with $\mathrm{KMnO}_{4}$ to oxidize organic impurities followed by subsequent distillation. The water extracts were concentrated, derivatized and analysed by the methods described above.
Measurement of DOC and TOC in rain and snow samples

Wet precipitation samples were filtered through a preheated $\left(500^{\circ} \mathrm{C}\right)$ Pallflex quartz fiber filter for the measurement of DOC: according to the manufacturer $99.99 \%$ of the dioctylphthalate particles $(0.3 \mu \mathrm{m})$ are retained on the filter under atmospheric conditions. An aliquot of unfiltered and filtered samples $(4 \mathrm{ml})$ were taken in the $7 \mathrm{ml}$ pre-heated $\left(450^{\circ} \mathrm{C}\right)$ glass screw vials with a Teflon-lined cap. After acidification with $1.2 \mathrm{M} \mathrm{HCl}$ solution $(50 \mu \mathrm{l})$, the samples were bubbled with pure nitrogen gas for $3 \mathrm{~min}$ to purge inorganic carbon. The water sample $(20-50 \mu l)$ was injected to a Shimadzu TOC-500 carbon analyser with a combustion column packed with a platinum-coated alumina (Kawamura et al., 1992). Injections were repeated five times for each sample. Two data sets having the highest and lowest values were discarded, whereas the remaining three values were averaged and used for TOC and DOC values in this study. The analytical precision of the procedure was within $2 \%$. Particulate organic carbon (POC) was calculated by the difference between TOC and DOC values. The data presented here are corrected for the system blanks.

\section{Measurements of $T C, T N$ and WSOC in aerosol samples}

A part of the filter sample (ca. $5 \mathrm{~cm}^{2}$ ) was cut off and subjected to a CHN corder (Yanagimoto MT-3) for the determination of TC and TN. Analytical errors for TC and TN based on duplicate analyses were 10 and $9 \%$, respectively. WSOC in the aerosol samples was also measured by the following method. A part of the aerosol filter samples ( $\mathrm{ca}$. $20 \mathrm{~cm}^{2}$ ) was cut in pieces and extracted with a pure water $(20 \mathrm{ml})$ for $5 \mathrm{~min}$ under ultrasonication. The water extracts were then filtered on Pallflex quartz fiber filter to remove particles and filter debris. An aliquot $(4 \mathrm{ml})$ of filtrates was taken in the $7 \mathrm{ml}$ pre-combusted $\left(450^{\circ} \mathrm{C}\right)$ glass screw vials with a Teflon-lined cap and acidified with $1.2 \mathrm{M} \mathrm{HCl}$. After purging the dissolved inorganic carbon with $\mathrm{N}_{2}$, the samples were analysed for WSOC by the method described above for DOC measurement. Analytical precision of the WSOC measurement was $2 \%$ based on duplicate analysis of the filter sample (24-25 February)

\section{RESULTS AND DISCUSSION}

\section{TC, TN and WSOC in aerosol samples}

Table 1 gives concentrations of aerosol mass, TC and total nitrogen $T N$, and WSOC in the aerosol samples. The concentration range of $\mathrm{TC}$ was 11-64 $\mu \mathrm{g} \mathrm{m}^{-3}$ (av. $32 \mu \mathrm{g} \mathrm{m}^{-3}$ ), which comprised $5.7-19 \%$ of total aerosol mass. These results are similar to the studies on carbonaceous fraction in total aerosol mass in the urban atmosphere: $17 \%$ in Beijing (Sekine et al., 1992), 20\% in Seoul (Hashimoto et al., 1991), 30\% in southern California (Appel et al., 1983). Interestingly, summer samples showed 4-6 times higher TC concentrations than the winter samples. Relative abundance of $\mathrm{TC}$ in aerosol mass was also higher in the summer samples (17-19\%) than the winter samples $(6-7 \%)$. These results seem to suggest that more particulate organic matter is produced in the summer probably by the photochemical gas-toparticle conversion (Warneck, 1988; Turpin and Huntzicker, 1991).

Concentrations of $\mathrm{TN}$ were $2-18 \mu \mathrm{g} \mathrm{m}^{-3}$ in the aerosol samples, which are 3-5 times lower than the TC contents. However, they still comprise a significant 
Table 1. Total carbon (TC) and nitrogen (TN) contents and water soluble organic carbon (WSOC) in the urban aerosol samples collected from Tokyo, 1992

\begin{tabular}{|c|c|c|c|c|}
\hline $\begin{array}{l}\text { Sampling date } \\
\text { Sampling time }\end{array}$ & $\begin{array}{c}24-25 \text { February } \\
20: 10-17: 45\end{array}$ & $\begin{array}{c}25-26 \text { February } \\
18: 00-17: 55\end{array}$ & $\begin{array}{c}22-23 \text { July } \\
22: 25-4: 40\end{array}$ & $\begin{array}{c}23 \text { July } \\
4: 40-18: 20\end{array}$ \\
\hline Aerosol mass $\left(\mu \mathrm{g} \mathrm{m}^{-3}\right)$ & 166 & 186 & 389 & 216 \\
\hline $\mathrm{TC}\left(\mu \mathrm{gC} \mathrm{m} \mathrm{m}^{-3}\right)$ & 11.3 & 10.6 & 64.0 & 42.0 \\
\hline TC/aerosol (\%) & 6.8 & 5.7 & 17.1 & 19.4 \\
\hline $\mathrm{TN}\left(\mu \mathrm{gN} \mathrm{m}{ }^{-3}\right)$ & 2.0 & 3.1 & 17.9 & 10.9 \\
\hline TN/aerosol (\%) & 1.2 & 1.7 & 4.6 & 5.0 \\
\hline $\mathrm{C} / \mathrm{N}$ ratio & 5.6 & 3.4 & 3.7 & 3.9 \\
\hline WSOC $\left(\mu \mathrm{gC} \mathrm{m} \mathrm{m}^{-3}\right)$ & 3.2 & 3.4 & 21.3 & 23.2 \\
\hline WSOC/aerosol mass (\%) & 1.9 & 1.8 & 5.5 & 10.7 \\
\hline WSOC/TC (\%) & 28 & 32 & 32 & 55 \\
\hline
\end{tabular}

portion of total aerosol mass $(1.2-5.0 \%$ of total aerosols). The $\mathrm{C} / \mathrm{N}$ weight ratios ranged from 3.4 to 5.6 with an average of 4.2 . The summer samples showed higher TN contents ( $c a .3-8$ times) than winter samples. The relative abundance of TN in total aerosol mass also showed higher values in the summer samples $(4.6-5.0 \%)$ than winter samples $(1.2-1.7 \%)$, suggesting that enhanced photochemical oxidations of $\mathrm{NO}_{\boldsymbol{x}}$ result in an increased concentration of particulate nitrate in the atmosphere. Although there is no reported data on TN, Satsumabayashi et al. (1990) indicated that $\mathrm{NO}_{3}{ }^{-}$and $\mathrm{NH}_{4}{ }^{+}$comprised 10 and $11 \%$ of total aerosol mass in Takasaki, being consistent with the present results.

WSOC showed a concentration range of $3.2-23 \mu \mathrm{g} \mathrm{m}^{-3}$, which comprised from 1.8 to $10.7 \%$ of total aerosol mass. Interestingly, WSOC contents are ca. 7 times higher in summer than winter samples (see Table 1). The relative abundance of WSOC in aerosols is also higher in summer $(5.5-10.7 \%)$ than winter samples (1.8-1.9\%), suggesting that WSOC including diacids and other water soluble organic compounds, are produced more in the summer than the winter season. Although WSOC fraction may contain waterinsoluble carbon such as black carbon in fine particle size $(>0.3 \mu \mathrm{m})$ which may partly pass through the Pallfex quartz fiber filter during filtration, we feel that a possible overestimation of WSOC is not significant. The WSOC was found as a significant fraction of total aerosol carbon: WSOC accounted for $28-55 \%$ of total aerosol carbon. Interestingly, WSOC/TC ratios were higher in the aerosol samples collected during day time than those collected at night time (see Table 1). This result suggests that water-soluble organic compounds in the urban aerosols are enriched during day time probably due to an enhanced photochemical production of polar compounds such as dicarboxylic acids.

During wet precipitation process, aerosol particles are scavenged from the atmosphere and their WSOC fraction should dissolve in water droplets, as well as gaseous organic compounds, and contribute to dissolved organic carbon in the wet precipitation samples. By contrast, water insoluble organic fraction of aerosol particles would contribute to POC in the wet precipitation samples.

\section{TOC, DOC and POC in snow and rain samples}

Table 2 gives TOC, DOC, and POC contents in the wet precipitation samples. TOC range in snow/sleet samples was $23-27 \mathrm{mgC}^{-1}$ (av. $25 \mathrm{mgC} \ell^{-1}$ ) whereas that of rain samples was $1.2-15.4 \mathrm{mgC}^{-1}$ (av. $4.9 \mathrm{mgC} \ell^{-1}$ ). Higher TOC values in the snow/ sleet samples may be caused by a better efficiency in scavenging organic compounds from the atmosphere by snow flakes than rain droplets. Because snow flakes have more surface area than rain drops in terms of a unit of weight, they may effectively adsorb and scavenge other water soluble organic compounds such as aldehydes, volatile fatty acids and ketones. The TOC values in rainwaters are similar to those reported for Los Angeles rainwaters (5-10 $\mathrm{mgC} \ell^{-1}$, Liljestrand and Morgan, 1980; Kawamura and Kaplan, 1991). As seen in Table 2, organic carbon in the precipitation was found mostly in the dissolved form (71-99\%, av. $90 \%$ ). Our results seemed to be in good agreement with the previous results of Likens et al. (1983), who reported the organic matter lower than $1000 \mathrm{Da}$ were dominant and gave DOC/TOC ratios higher than 0.7 in New Hampshire rains. Because combustion-derived fine carbon particles such as black carbon are present abundantly in urban atmosphere (Appel et al., 1983; Goldberg, 1985; Turpin and Huntzicker, 1991), they may be present in the precipitation samples in colloidal size, suggesting that black carbon may represent a certain fraction of DOC.

In the rain event II (1 August), the second rain showed higher TOC and DOC values than the first rain (Table 2). This is probably caused by more efficient scavenging of organic materials due to much lower precipitation rate in the second rain. By contrast, during rain event I (30 June) in which precipitation rates were rather stable (see Table 2), both DOC and TOC concentrations decreased as a function of time, suggesting that organic compounds were scavenged from the atmosphere during an early stage of wet precipitation. However, a fractionation seemed 


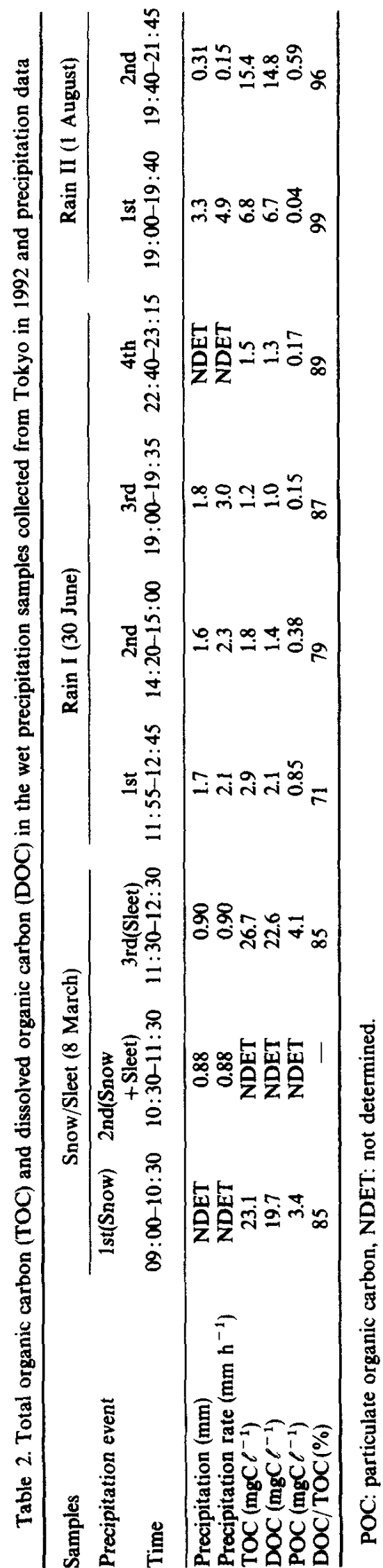

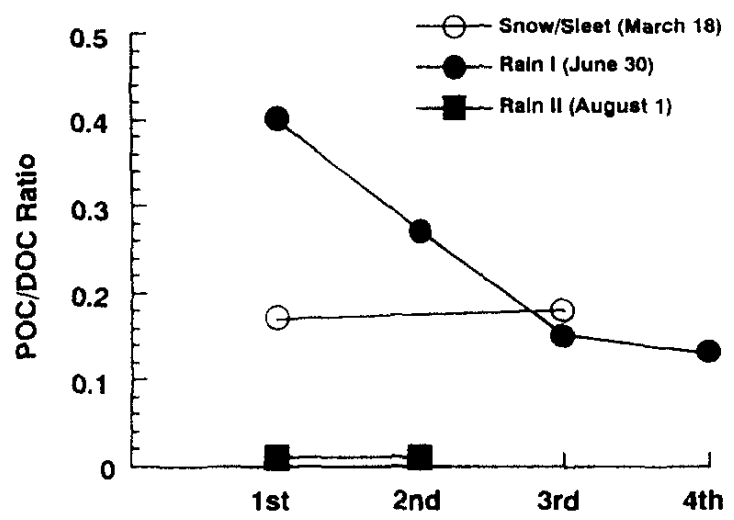

Fig. 1. Changes in the particulate organic carbon (POC)/dissolved organic carbon (DOC) ratios in the rain and snow samples during precipitation events.

to occur during wet precipitation between water soluble and water insoluble organic matter in the air. As shown in Fig. 1, POC/DOC ratios decreased as a function of time from 0.43 to 0.15 during rain event $I$. Generally, POC originates only from water-insoluble fraction of aerosol particles whereas DOC originates from both water-soluble fraction of aerosols and gaseous organic components in the atmosphere. It is unlikely that the water-insoluble fraction of the aerosols is more effectively scavenged than the watersoluble fraction of the aerosols. Thus, the present results (Fig.1) suggest that aerosol particles are more efficiently scavenged from the air than gaseous organic compounds.

Distribution of dicarboxylic acids, ketoacids and dicarbonyls in snow and rain samples

Figure 2 shows a reconstructed ion chromatogram of derivatives of dicarboxylic acids, ketocarboxylic acids and dicarbonyls isolated from the snow sample. A homologous series of straight-chain saturated $\left(\mathrm{C}_{2}-\mathrm{C}_{9}\right)$ dicarboxylic acids were identified in the snow/ sleet and rainwater samples together with branchedchain (iso) saturated $\left(\mathrm{C}_{4}, \mathrm{C}_{5}\right)$, aliphatic unsaturated (maleic: cis $\mathrm{C}_{4}$, fumaric: trans $\mathrm{C}_{4}$, methylmaleic: cis $\mathrm{C}_{5}$, aromatic (phthalic: $\mathrm{C}_{8}$ ), oxo (oxomalonic, $\mathrm{C}_{3}$ ) and hydroxy (malic: $\mathrm{C}_{4}$ ) diacids. As seen in Fig. 2, the diacid distribution is generally characterized by a predominance of oxalic acid, followed by either succinic $\left(C_{4}\right)$, azelaic $\left(C_{9}\right)$ or phthalic $\left(C_{8}\right)$ acid. Unsaturated diacids showed a predominance of cisconfiguration (maleic acid) over trans-configuration (fumaric acid). In addition to diacids, ketocarboxylic acids and dicarbonyls were also detected in the samples. The ketocarboxylic acids detected in the wet precipitations include pyruvic acid $\left(\mathrm{C}_{3}\right)$ and a homologous series of w-oxocarboxylic acids $\left(\mathrm{C}_{2}-\mathrm{C}_{6}, \mathrm{C}_{9}\right)$. The dicarbonyl group includes glyoxal $\left(C_{2}\right)$ and methylglyoxal $\left(C_{3}\right)$. Among these three compound classes, the diacid group was the most abundant.

Table 3 gives concentrations of individual diacids as well as ketoacids and dicarbonyls in wet precipitation 


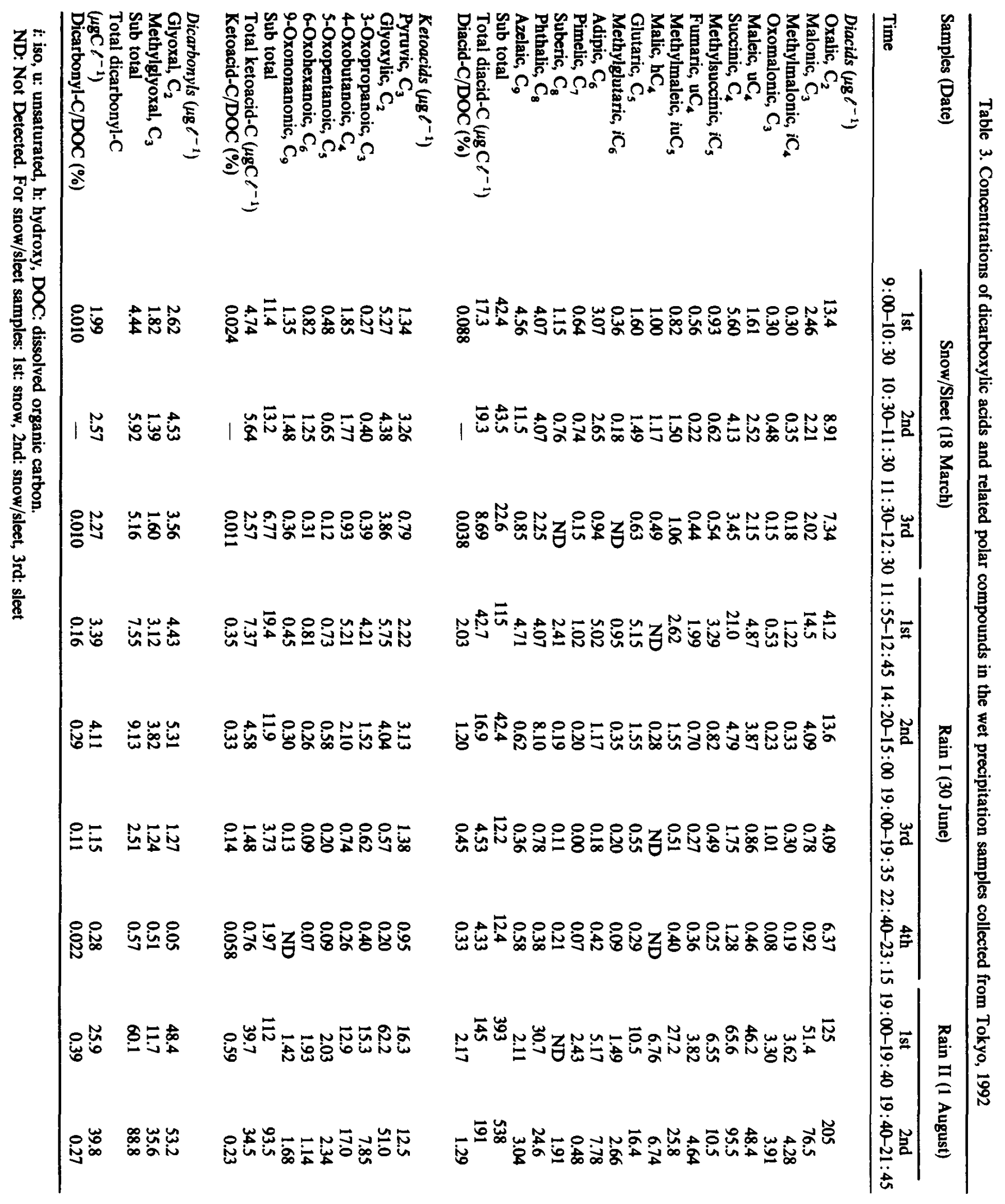




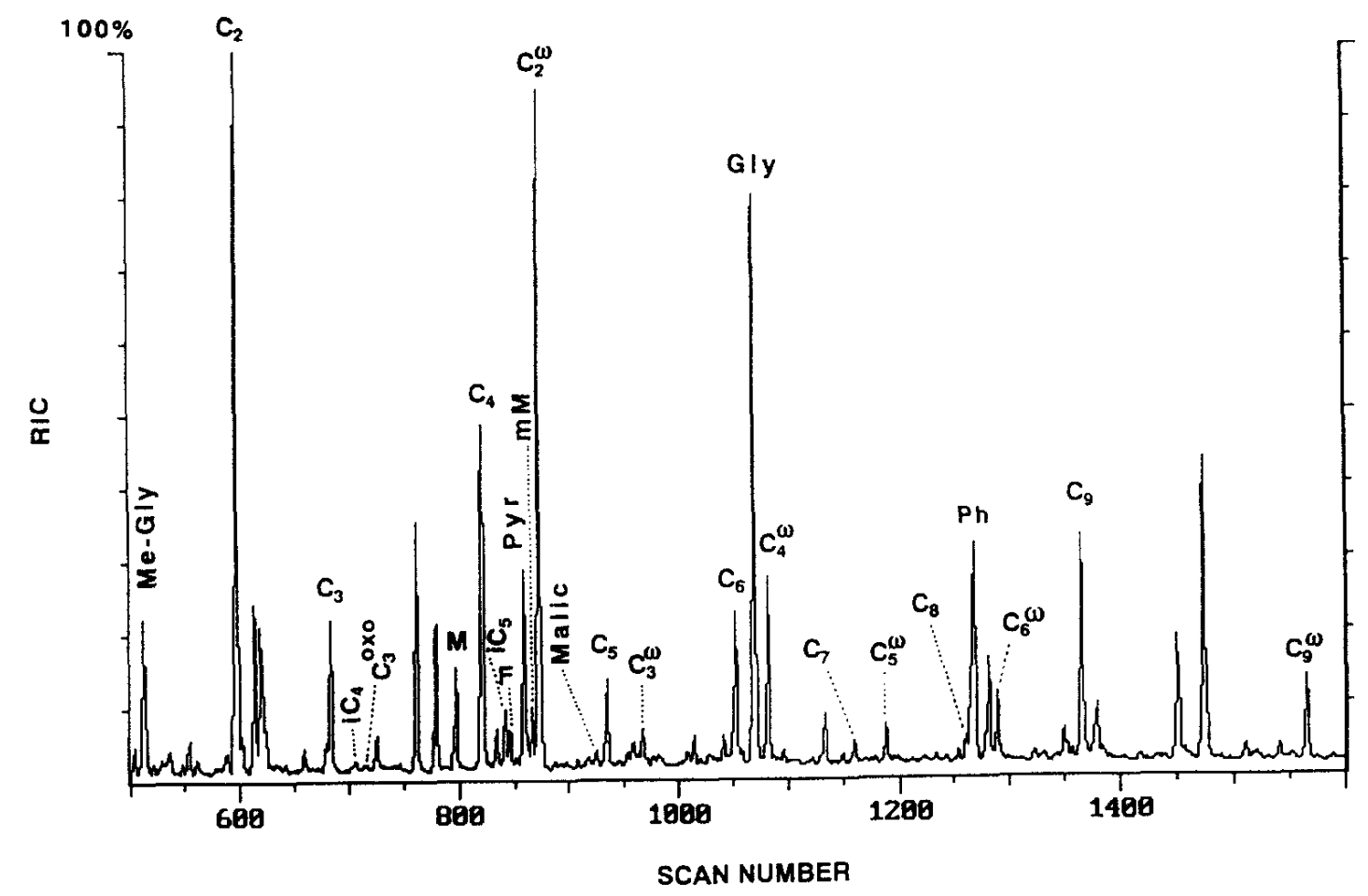

Fig. 2. A reconstructed total ion chromatogram (RIC) of the derivatives of dicarboxylic acids, ketocarboxylic acids and dicarbonyls isolated from the snow sample (the first snow, $18 \mathrm{March} \mathrm{1992)} \mathrm{collected} \mathrm{in} \mathrm{Tokyo.} \mathrm{For}$ abbreviation, see Table 3. $\mathrm{C}_{n}$ means dicarboxylic acid with $n$ carbon numbers. $i \mathrm{C}_{n}$ indicates branched-chain (iso) diacid. $M, F$ and $\mathrm{mM}$ are maleic, fumaric and methylmaleic acids, respectively. $C_{n} \omega$ indicates $\omega$-oxocarboxylic acid with $n$ carbon numbers. Malic, Gly, Me-Gly, Ph and Pyr mean malic acid, glyoxal, methylglyoxal, phthalic acid and pyruvic acid, respectively.

samples. Concentration ranges of the total dicarboxylic acids $\left(\mathrm{C}_{2}-\mathrm{C}_{9}\right)$ were $23-43 \mu \mathrm{g} \ell^{-1}$ in the snow/sleet samples and $12-538 \mu \mathrm{g} \ell^{-1}$ in the rain samples. On the other hand, ketoacids were less abundant than diacids: their concentration ranges were $6.8-114 \mu \mathrm{g} \ell^{-1}$ in the snow/sleet samples and $2.0-112 \mu \mathrm{g} \ell^{-1}$ in the rainwater samples. Concentrations of dicarbonyls were much lower than diacids and ketoacids: their concentration ranges were $4.4-5.9 \mu \mathrm{g} \ell^{-1}$ in the snow/sleet samples and $0.6-89 \mu \mathrm{g} \ell^{-1}$ in the rainwater samples. The August rain samples (rain II, 1 August) showed higher concentrations of these compound classes compared to other precipitation samples. This is probably because the diacids were more accumulated in the atmosphere under the condition of intensive solar radiation which continued for several days before the precipitation event and were apparently more concentrated in the rainwaters due to the low precipitation rate during the rain event (Table 2 ).

Oxalic acid $\left(C_{2}\right)$ was found to be the most abundant diacid species in the wet precipitation samples studied, except for one snow/sleet sample which showed a predominance of azelaic acid $\left(C_{9}\right)$. This feature has been obtained in the aerosol samples from central Tokyo (Kawamura and Ikushima, 1993). However, relative abundance of oxalic acid in the total diacids largely fluctuate among the precipitation samples: the
$\mathrm{C}_{2}$ diacid comprised only $21-32 \%$ of the total diacids (av. $28 \pm 5.4 \%$ ) in the snow/sleet samples whereas that in the rain samples comprised from 32 to $52 \%$ of the total diacids (av. $37 \pm 7 \%$ ). Similar low values for $\mathrm{C}_{2}$ diacid have been reported in Greenland snow and ice samples (Kawamura and Yasui, 1991). The second most abundant species was succinic acid $\left(\mathrm{C}_{4}\right)$ followed by azelaic $\left(C_{9}\right)$, phthalic or malonic acid $\left(C_{3}\right)$ in the wet precipitation samples. The $\mathrm{C}_{4}$ diacid comprised 9.5-15.2\% (av. $13 \pm 2 \%$ ) in the snow/sleet samples whereas it comprised $10.4-18.3 \%$ (av. $15 \pm 3 \%$ ) in the rain samples. The $\mathrm{C}_{9}$ diacid comprised $0.5-26 \%$ (av. $6.1 \pm 8.2 \%$ ), whereas phthalic acid comprised 3-19\% (av. $8.1 \pm 4.9 \%$ ) of the total diacids in the wet precipitation samples. The $\mathrm{C}_{3}$ diacid accounted for $6-9 \%$ $(7 \pm 2 \%)$ in snow/sleet samples whereas it accounted for $6-14 \%$ (av. $11 \pm 3 \%$ ) in the rainwaters.

Among ketocarboxylic acids, pyruvic or glyoxylic acid generally were the dominant species. It is of interest to note that glyoxylic acid $\left(C_{2}\right)$ is always the most abundant $\omega$-oxocarboxylic acid in both snow and rain samples, followed by $\mathrm{C}_{4}$ or $\mathrm{C}_{3}$ species. The higher $\omega$-oxoacids are less abundant. Their molecular distributions seem to be consistent with those of dicarboxylic acids, suggesting that these ketoacids are one of the precursors of dicarboxylic acids. It is also interesting to note that glyoxal is as abundant as 
Table 4. Cencentrations of dicarboxylic acids and related polar compounds in the aerosol samples from Tokyo 1992

\begin{tabular}{|c|c|c|c|c|}
\hline $\begin{array}{l}\text { Date } \\
\text { Time }\end{array}$ & $\begin{array}{l}\text { 24-25 Feb. } \\
20: 10-17: 45\end{array}$ & $\begin{array}{l}\text { 25-26 Feb. } \\
18: 00-17: 55\end{array}$ & $\begin{array}{c}22-23 \text { July } \\
22: 25-4: 40\end{array}$ & $\begin{array}{c}23 \text { July } \\
4: 40-18: 20\end{array}$ \\
\hline \multicolumn{5}{|l|}{ Diacids (ng m $\mathrm{m}^{-3}$ ) } \\
\hline Oxalic, $\mathrm{C}_{2}$ & 521 & 650 & 1352 & 1680 \\
\hline Malonic, $\mathbf{C}_{3}$ & 105 & 129 & 322 & 453 \\
\hline Methylmalonic, $i C_{4}$ & 8.8 & 22 & 22 & 42 \\
\hline Oxomalonic, $\mathbf{C}_{3}$ & 30 & 32 & 24 & 46 \\
\hline Maleic, $\mathrm{uC}_{4}$ & 29 & 33 & 26 & 21 \\
\hline Succinic, $\mathrm{C}_{4}$ & 139 & 142 & 279 & 251 \\
\hline Methylsuccinic, $i C_{5}$ & 24 & 30 & 12 & 18 \\
\hline Fumaric, $\mathrm{uC}_{4}$ & 12 & 20 & 44 & 10 \\
\hline Methylmaleic, iuC $\mathrm{C}_{5}$ & ND & ND & ND & ND \\
\hline Malic, $\mathrm{hC}_{4}$ & 17 & 47 & 73 & 63 \\
\hline Glutaric, $\mathrm{C}_{5}$ & 39 & 48 & 81 & 88 \\
\hline Methylglutaric, $i C_{6}$ & 10 & 24 & ND & 5.3 \\
\hline Adipic, $\mathrm{C}_{6}$ & 35 & 54 & 31 & 79 \\
\hline Pimelic, $\mathrm{C}_{7}$ & 6.1 & 11.0 & ND & 38 \\
\hline Suberic, $\mathrm{C}_{8}$ & 0.79 & 6.8 & ND & 12 \\
\hline Phthalic, $\mathrm{C}_{\mathbf{8}}$ & 130 & 85 & 135 & 157 \\
\hline Azelaic, $\mathrm{C}_{9}$ & 41 & 46 & 43 & 48 \\
\hline Sub total & 1150 & 1379 & 2443 & 3012 \\
\hline Total diacid-C $\left(\mathrm{ng} \mathrm{m}^{-3}\right)$ & 422 & 492 & 817 & 1001 \\
\hline Diacids/aerosol mass (\%) & 0.69 & 0.74 & 0.63 & 1.39 \\
\hline Diacid-C/TC (\%) & 3.70 & 4.60 & 1.28 & 2.40 \\
\hline Diacid-C/WSOC (\%) & 13.2 & 14.5 & 3.8 & 4.3 \\
\hline \multicolumn{5}{|l|}{ Ketoacids (ng $\mathrm{m}^{-3}$ ) } \\
\hline Pyruvic, $C_{3}$ & 45 & 41 & 27 & 89 \\
\hline Glyoxylic, $\mathbf{C}_{2}$ & 120 & 161 & 174 & 238 \\
\hline 3-Oxopropanoic, $\mathrm{C}_{3}$ & 17 & 18 & 31 & 28 \\
\hline 4-Oxobutanoic, $\mathrm{C}_{4}$ & 55 & 28 & 45 & 70 \\
\hline 5-Oxopentanoic, $\mathrm{C}_{5}$ & 8.9 & 9.3 & 17 & 29 \\
\hline 6-Oxohexanoic, $\mathrm{C}_{6}$ & 7.9 & 5.0 & 9.5 & 16 \\
\hline 9-Oxononanoic, $\mathrm{C}_{9}$ & 12 & 7.6 & 22 & 8.8 \\
\hline Sub total & 265 & 270 & 326 & 479 \\
\hline Total ketoacid-C $\left(\mathrm{ngC} \mathrm{m}^{-3}\right)$ & 104 & 99 & 125 & 180 \\
\hline Ketoacids/aerosol mass (\%) & 0.16 & 0.15 & 0.084 & 0.22 \\
\hline Ketoacid-C/TC (\%) & 0.92 & 0.93 & 0.19 & 0.46 \\
\hline Ketoacid-C/WSOC (\%) & 3.2 & 2.9 & 0.58 & 0.78 \\
\hline \multicolumn{5}{|l|}{ Dicarbonyls (ng $\mathrm{m}^{-3}$ ) } \\
\hline Glyoxal, $\mathrm{C}_{2}$ & 45 & 38 & 43 & 46 \\
\hline Methylglyoxal, $\mathrm{C}_{3}$ & 24 & 67 & 40 & 39 \\
\hline Sub total & 69 & 105 & 83 & 90 \\
\hline Total dicarbonyl-C $\left(\mathrm{ngC} \mathrm{m}^{-3}\right)$ & 31 & 49 & 38 & 39 \\
\hline Dicarbonyls/aerosol mass $(\%)$ & 0.042 & 0.056 & 0.021 & 0.042 \\
\hline Dicarbonly-C/TC (\%) & 0.27 & 0.47 & 0.059 & 0.092 \\
\hline Dicarbonly-C/WSOC (\%) & 0.96 & 1.5 & 0.18 & 0.17 \\
\hline
\end{tabular}

TC: total carbon in aerosols, WSOC: water soluble organic carbon in aerosols.

glyoxylic acid in the wet precipitation samples. Glyoxal and methylglyoxal have been reported in the marine air (Zhou and Mopper, 1990), rain and fog samples (Steinberg and Kaplan, 1984; Munger et al., 1990) and snow and ice samples from Greenland (Kawamura and Yasui, 1991). They are produced by the photochemical oxidation of aromatic hydrocarbons such as benzene and toluene (Bandow et al., 1985). These dicarbonyls may be intermediates in the photochemical oxidation reactions of aromatic hydrocarbons to oxalic acid (Norton et al., 1983).
Distribution of dicarboxylic acids, ketoacids and dicarbonyls in aerosol samples

The dicarboxylic acids $\left(\mathrm{C}_{2}-\mathrm{C}_{9}\right)$, ketoacids $\left(\mathrm{C}_{2}-\mathrm{C}_{6}\right.$, $\left.\mathrm{C}_{9}\right)$ and dicarbonyls $\left(\mathrm{C}_{2}-\mathrm{C}_{3}\right)$ were also detected in aerosol samples. Molecular distributions of these compounds are roughly similar to those of wet precipitations. The concentration ranges of total diacids, ketoacids and dicarbonyls were 1150-3010, 265-479 and 69-105 $\mathrm{ng} \mathrm{m}^{-3}$, respectively. They accounted for $0.6-1.4 \%$ (av. 0.9\%), 0.08-0.2\% (av. 0.15\%) and $0.04-0.21 \%$ (av. $0.09 \%$ ) of total aerosol mass, 
respectively. Interestingly, dicarboxylic acids comprise a significant fraction of aerosol TC and WSOC; $1.3-4.6 \%$ (av. 3.0\%) of TC and 3.8-15\% (av. 9\%) of WSOC. These results suggest that diacids can be important contributor to DOC in wet precipitations. On the other hand, ketoacids accounted for less significant fraction of TC and WSOC: $0.2-0.9 \%$ (av. $0.6 \%$ ) of aerosol TC and for $0.6-3.2 \%$ (av. $1.7 \%$ ) of WSOC. By contrast, dicarbonyls accounted for only $0.1-0.5 \%$ of aerosol TC and $0.2-1.5 \%$ of WSOC. These water soluble compounds should partly contribute to the DOC in the wet precipitation samples.

The diacid molecular distributions in the present aerosol samples are similar to those reported in the central Tokyo by Kawamura and Ikushima (1993). As seen in Table 4, oxalic acid $\left(C_{2}\right)$ was found to be the most abundant $(51 \%)$ followed by malonic $\left(\mathrm{C}_{3}\right)$ or succinic $\left(C_{4}\right)$ acid. The $C_{3}$ and $C_{4}$ diacids represents 12 and $11 \%$ of the total diacids, respectively. These three species accounted for $70 \%$ (av.) of total diacids detected. Phthalic acid was the forth most abundant followed by glutaric $\left(C_{5}\right)$, azelaic and/or adipic as well as malic acid (hydroxy dicarboxylic acid). Interestingly, the relative abundance of shorter chain diacids $\left(C_{2}\right.$, $\mathrm{C}_{3}$ ) are lower in the winter than the summer samples. Thus, succinic acid is the second most abundant diacid (av. $11 \%$ ) in February aerosols followed by malonic (av. 9\%) whereas the opposite situation was observed for the samples collected in July. Azelaic acid represented $4 \%$ (av.) of the winter aerosols and $2 \%$ (av.) of those of summer time. This seems to indicate that strong solar radiations and subsequent oxidation reactions of precursors produce preferentially oxalic and malonic acid, being consistent without previous results (Kawamura and Ikushima, 1993).

\section{Comparative distribution of dicarboxylic acids in wet precipitations and aerosols}

The distributions of diacids in ambient aerosols and wet precipitation samples are not directly comparable; however, their molecular distribution and relative abundance in DOC (for the rains and snows), or in TC (for aerosols) may give us an insight on physico- chemical processes or vertical distribution of polar organic compounds in the air column. Although oxalic acid was generally the predominant diacid in snow, rain and aerosol samples, its relative abundance in the total diacids showed a diversity; $28 \%$ (snow), $37 \%$ (rain) and $51 \%$ (aerosols), as stated above. As shown in Fig. 3, oxalic acid accounted for $34 \%$ of total diacids in the wet precipitation samples whereas this acid comprised $51 \%$ in the aerosol samples. The shorter chain aliphatic diacids $\left(C_{2}\right.$ and $\left.C_{3}\right)$ are depleted in rain and snow samples: they represented 43 and $62 \%$ of total diacids in the wet precipitation and aerosol samples, respectively. The difference in the diacid distribution between the two sample types may suggest that (1) oxalic and malonic acids are depleted by selective degradation in the rain droplets or in the storage bottles, or (2) oxalic acid is enriched in the atmosphere near ground level and relatively depleted in upper levels of the troposphere.

Biological degradation of the oxalic acid after wet deposition is unlikely, because rainwater samples were protected from biological activity during sample collection and sample storage by mercuric chloride added to the samples. This consideration is also supported by the fact that $\mathrm{C}_{2}$ diacid is also relatively depleted in snow/sleet samples (Table 3), in which biodegradation is very unlikely during the snow fall. Chemical (nonbiological) degradation of oxalic acid cannot be excluded; however, it is not easy to explain the selective degradation of oxalic acid in the falling rain drops and during storage: samples were stored in the brown glass bottles in darkness. We feel that post-depositional depletion of oxalic and malonic acids during precipitation or sample storage is not the case. Thus, the latter case is more likely.

The aerosol samples were collected near the ground surface, whereas the rain droplets and snow flakes scavenge the dicarboxylic acids from the air column including upper levels of the troposphere (probably few hundred meters to few kilometers above the ground). Thus, the difference in the molecular distributions of diacids between wet precipitation and aerosol samples may reflect the difference in the diacid distributions in the ground level and upper levels of the

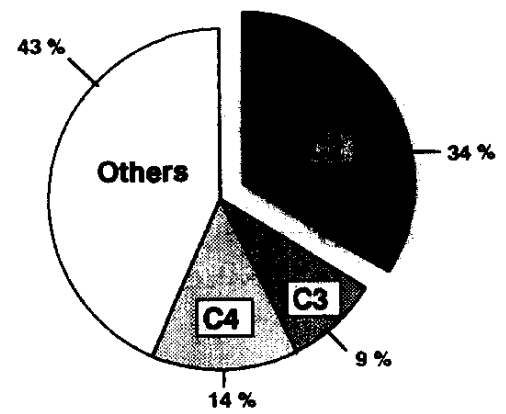

(a) Snow/Sleet/Rain

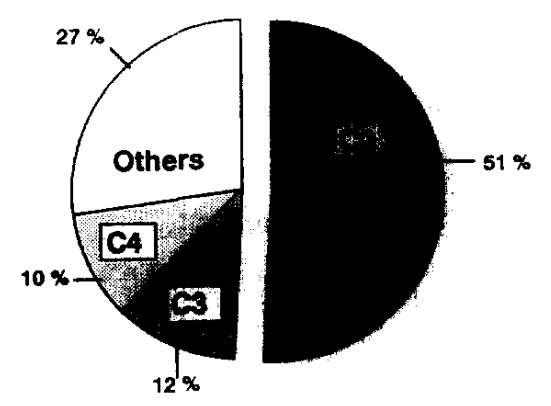

(b) Aerosols

Fig. 3. Pie diagrams of the averaged relative abundance $(\%)$ of oxalic $\left(\mathrm{C}_{2}\right)$, malonic $\left(C_{3}\right)$, succinic $\left(C_{4}\right)$ and other dicarboxylic acids in (a) snow/sleet and rain samples $(n=9)$, and (b) aerosol samples $(n=4)$ collected in the Tokyo area. 
troposphere. Although there is no comparison study on diacid distributions between the lower and upper troposphere, it is likely that oxalic acids are more extensively produced near the ground levels than the upper levels of the troposphere. Our previous observations of diacids near the ground surface of Tokyo atmosphere indicated that concentrations of dicarboxylic acids largely increased in the summer season with oxalic acid being predominant $\left(\mathrm{C}_{2}: 52 \%\right.$ of total diacids for annual average, Kawamura and Ikushima, 1993). Major photochemical precursors of the oxalic acid have been considered as aromatic hydrocarbons such as benzene and toluene emitted from anthropogenic sources (Kawamura and Ikushima, 1993). Because these aromatic hydrocarbons are photochemically reactive, they may be mostly oxidized near the ground level and are unlikely transported high enough to the upper troposphere.

Although LMW diacids are mostly present as aerosol particles in the atmosphere (Kawamura and Kaplan, 1987), they could be partly present in the gaseous phase, in which case oxalic acid should be enriched compared to higher diacids. If this is the case, wet precipitation samples should show higher relative abundance of oxalic acid than aerosol samples because rain droplets and snow flakes scavenge, in addition to aerosols, gaseous diacids. However, such a result was not obtained in this study (see Fig. 3). Hence, our results indicate that the molecular distributions of dicarboxylic acids are not vertically homogeneous in the air column of the troposphere (from the ground to upper levels). A possible depletion of oxalic acid in the upper troposphere may also be caused by preferential degradation of oxalic acid, which is probably exposed to stronger solar radiation.

\section{Relative abundance of polar compounds in DOC and wet scavenging process}

The concentrations of major diacids and ketoacids generally decreased as a function of time during the precipitation event, except for the rain event II (1 August) whose precipitation rates largely changed during the rainfall (see Tables 2 and 3). These results suggest that diacids and ketoacids in the atmosphere are scavenged in an early stage of wet precipitation event. During the wet scavenging processes of these polar compounds, there seems no clear trend which suggests a systematical molecular discrimination. On the other hand, concentrations of dicarbonyls did not show a clear decreasing trend with time (Table 3), although their concentrations seemed to decrease with time in the rain event $I$. Interestingly, concentrations of diacids clearly decreased during the precipitation events as a function of time when diacid-carbon contents are normalized by DOC.

The $\mathrm{C}_{2}-\mathrm{C}_{9}$ diacid-carbon contents are also presented in Table 3 . Total diacid-C range was 8.7-17 $\mu \mathrm{g} \mathrm{C} \ell^{-1}$ in the snow/sleet samples whereas that was 4-191 $\mu \mathrm{g} \mathrm{C} \ell^{-1}$ in the rain samples. Their relative abundance in DOC was $0.04-0.09 \%$ in the snow/sleet samples. By contrast, the relative abundance of diacid-C in DOC in the rainwater samples (0.33-2.1\%) was much higher than those of the snow/ sleet samples. The lower values in the snow/sleet samples are probably caused by the higher DOC values in the snow/sleet samples: snow flakes may more efficiently adsorb and scavenge non-polar to polar volatile organic compounds as well as particulate organic compounds than rain droplets do, as pointed out before. Figure 4 plots the relative abundance (\%) of diacid-C, ketoacid-C and dicarbonyl-C contents in DOC of the precipitation samples as a function of time. The diacid-C/DOC decreased with time in all the precipitation events: for example, during rain event I, diacid-C/DOC decreased from the first rain $(2 \%)$ to the fourth rain $(0.3 \%)$. These results indicate that diacids which mostly exist as particles (Kawamura and Kaplan, 1987) are removed from the atmosphere during wet precipitation more efficiently than other water soluble organic compounds including volatile fatty acids and aldehydes.

Ketoacid-C/DOC ratios also showed a decreasing trend with time during precipitation events (Fig. 4). These results suggest that ketoacids are also preferentially scavenged from the air in a manner similar to diacids. By contrast, dicarbonyl-C/DOC ratios show a trend different from diacids and ketoacids. Their ratios remained rather constant in the snow/sleet event and largely increased in the second rain of rain event I (see Fig. 4). These results may suggest that wet scavenging process of glyoxal and methylglyoxal is different from diacids: the dicarbonyls may be significantly present in gaseous phase and their wet scavenging rate is less than that of diacids which are mostly present in particulate form. This is consistent with the results that glyoxal/oxalic acid ratios were greater in the wet precipitation samples $(0.11-0.49$, av. 0.33 , except for rain I, fourth sample, Table 3) than the aerosol samples (0.03-0.09, av. 0.05, Table 4).

Aerosol particles are removed from the atmosphere by collisional capture during below-cloud (washout) scavenging (Warneck, 1988). By contrast, water-soluble gas components are scavenged by sorption in cloud and rain droplets, which is controlled by thermodynamic equilibrium between gas and liquid phases. Thus, particulate organic matter may be more efficiently scavenged than gaseous organic components. Aerosol particles which contain LMW diacids at a concentration level of few percent, should participate in the cloud condensation nuclei (CCN) processes because the diacids are very water soluble thus likely to interact with water vapor. Therefore, the diacids in the atmosphere probably act as $\mathrm{CCN}$ and are involved in the in-cloud (rainout) scavenging processes in the upper troposphere. We propose that dicarboxylic acids are active $\mathrm{CCN}$ species and participate in an early stage of wet precipitation processes. These processes can partly explain why dicarboxylic acid carbon contents normalized by DOC are higher in the early stage of wet precipitation (Fig. 4). 

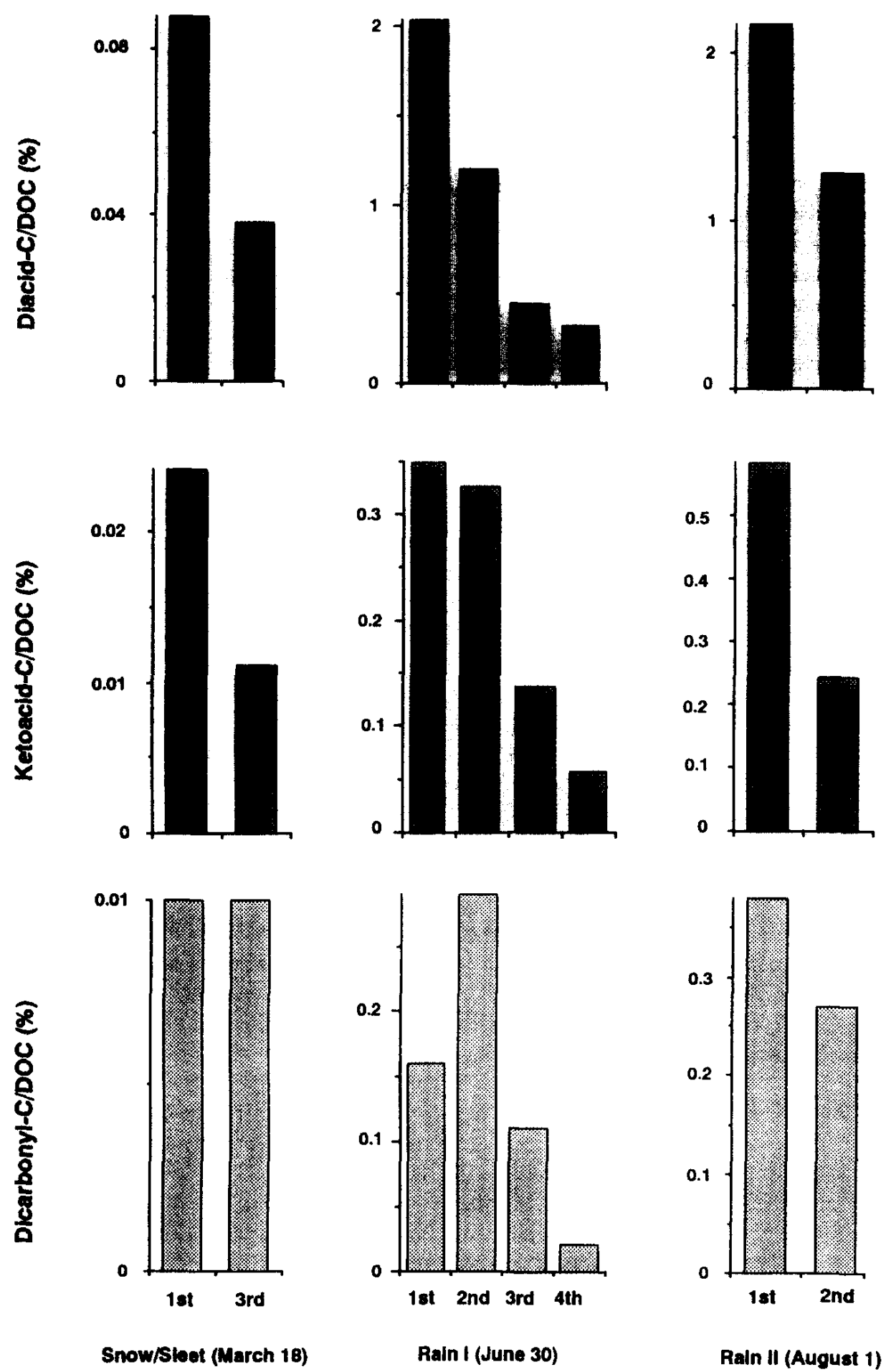

Fig. 4. Changes in relative abundance (\%) of dicarboxylic acids, ketoacids and dicarbonyls in dissolved organic carbon (DOC) in snow/sleet and rain samples as a function of time during wet precipitation events.

\section{SUMMARY AND CONCLUSION}

Low molecular weight $\left(\mathrm{C}_{2}-\mathrm{C}_{9}\right)$ dicarboxylic acids and related compounds have been detected in the snow/sleet and rain samples as well as aerosols collected from the urban atmosphere of Tokyo. Both wet precipitation and aerosol samples showed the predominance of oxalic acid $\left(\mathrm{C}_{2}\right)$; however, the diacid molecular distributions showed that, although they remained the most abundant, short chain diacids $\left(C_{2}\right.$,
$\mathrm{C}_{3}$ ) are depleted in wet precipitations. This trend seems to indicate that dicarboxylic acid composition of the ground level aerosols is different from those of upper levels of the troposphere. The $\mathrm{C}_{2}$ and $\mathrm{C}_{3}$ diacids in the upper tropospheric aerosols may be relatively depleted, probably due to preferential photochemical degradation of these species.

Time series of rainwater samples showed that the diacid concentrations decreased as a function of time, suggesting that dicarboxylic acids are significantly 
removed from the atmosphere by wet precipitation processes. Moreover, the relative abundance of dicarboxylic acid-carbon in dissolved organic carbon in wet precipitation samples decreased with time during rain events, suggesting that diacids are more effectively scavenged from the air by raindrops than other water-soluble organic compound classes such as aldehydes, ketones and volatile fatty acids. However, during wet precipitation events, systematic molecular fractionation was not observed in the distribution of diacids. This is consistent with that the diacids are present as particles in the atmosphere. Because of their water solubility and their significant concentration in the atmosphere, dicarboxylic acids may be important compound class which participate in in-cloud scavenging processes as $\mathrm{CCN}$.

Acknowledgements-We wish to acknowledge the Japan Society for the Promotion of Science (JSPS) for the post doctoral fellowship to R.S. This study was in part supported by the Ministry of Education, Science and Culture through Grant-in-Aid No. 03248104.

\section{REFERENCES}

Appel B. R., Tokiwa Y. and Kothny E. L. (1983) Sampling of carbonaceous particles in the atmosphere. Atmospheric Environment 17, 1787-1796.

Bandow H., Washida N. and Akimoto H. (1985) Ringcleavage reactions of aromatic hydrocarbons studied by FT-IR spectroscopy. I. Photooxidation of toluene and benzene in the $\mathrm{NO}_{x}$-air system. Bull. chem. Soc. Jpn 58, 2531-2540.

Cronn D. R., Charlson R. J., Knight R. L., Crittenden R. L. and Appel B. R. (1977) A survey of the molecular nature of primary and secondary components of particles in urban air by high-resolution mass spectroscopy. Atmospheric Environment 11, 929-937.

Goldberg E. D. (1985) Black Carbon in the Environment, p. 198. Wiley Interscience, New York.

Grosjean D. and Friedlander S. K. (1980) Formation of organic aerosols from cyclic olefins and diolefins. Adv envir. Sci. Technol. 9, 435-473.

Grosjean D., Van Cauwenberghe K., Schmid J. P., Kelley P. E. and Pitts J. N. Jr (1978) Identification of $C_{3}-C_{10}$ aliphatic dicarboxylic acids in airborne particulate matter. Envir. Sci. Technol. 12, 313-317.

Hashimoto Y., Kim H. K., Otoshi T. and Sekine Y.(1991) Air quality at Seoul, Korea, May-March 1989. J. Japan Soc. Air Pollut. 26, 51-58.

Hatakeyama S., Tanonaka T., Weng J., Bandow H., Takagi H. and Akimoto H. (1985) Ozone-cyclohexene reaction in air: quantitative analysis of particulate products and the reaction mechanism. Envir. Sci. Technol. 19, 935-942.

Kawamura K. and Gagosian R. B. (1987) Implication of $\omega$ oxocarboxylic acids in the remote marine atmosphere for photo-oxidation of unsaturated fatty acids. Nature 325, 330-332.
Kawamura K. and Kaplan I. R. (1987) Motor exhaust emissions as a primary source for dicarboxylic acids in Los Angeles ambient air. Envir. Sci. Technol. 21, 105-110.

Kawamura K. and Kaplan I. R. (1991) Organic compounds in rainwater. In Organic Chemistry of the Atmosphere (edited by Hansen L. D. and Eatough D. J.), pp. 233-284. CRC Press, Boca Raton, Florida.

Kawamura K. and Yasui O. (1991) Organic acids and aldehydes in the ice samples from Site-J, Greenland. Bull. Glacier Res. 9, 59-63.

Kawamura K. and Ikushima K. (1993) Seasonal changes in the distribution of dicarboxylic acids in the urban atmosphere. Envir. Sci. Technol. 27, 2227-2235.

Kawamura K. and Usukura K. (1993) Distributions of low molecular weight dicarboxylic acids in the North Pacific aerosol samples. J. Oceanogr. 49, 271-283.

Kawamura K., Steinberg S. and Kaplan I. R. (1985) Capillary GC determination of short-chain dicarboxylic acids in rain, fog and mist. Int. J. envir. analyt. Chem. 19, 175-188.

Kawamura K., Yokoyama K. and Fujii Y. (1992) Vertical profiles of total organic carbon and polar organic compounds in the ice core from Site-J, Greenland. Proc. NIPR Symp. Polar Met. Glaciol. 6, 99-105.

Likens G. E., Edgerton E. S. and Galloway J. N. (1983). The composition and deposition of organic carbon in precipitation. Tellus 35B, 16-24.

Liljestrand H. M. and Morgan J. J. (1980) Spatial variations of acid precipitation in Southern California. Envir. Sci. Technol. 15, 333-339.

Munger J. W., Collett J. Jr, Daube B. Jr and Hoffmann M. R. (1990) Fogwater chemistry at Riverside, California. Atmospheric Environment 24B, 185-205.

Norton R. B., Roberts J. M. and Huebert B. J. (1983) Tropospheric oxalate. Geophys. Res. Lett. 10, 517-520.

Satsumabayashi H., Kurita H., Yokouchi Y. and Ueda H. (1989) Mono- and di-carboxylic acids under long-range transport of air pollution in central Japan. Tellus 41B, 219-229.

Satsumabayashi H., Kurita H., Yokouchi Y. and Ueda H. (1990) Photochemical formation of particulate dicarboxylic acids under long-range transport in central Japan. Atmospheric Environment 24A, 1443-1450.

Schuetzle D., Cronn D. and Crittenden A. L. (1975) Molecular composition of secondary aerosol and its possible origin. Envir. Sci. Technol. 9, 838-845.

Sekine Y., Hashimoto Y., Nakamura T., Chen Z. and Mitsuzawa S. (1992) Characterization of atmospheric aerosol components at Beijing, China. J. Japan. Soc. Air Pollut. 27, 237-245.

Steinberg S. and Kaplan I. R. (1984) The determination of low molecular weight aldehydes in rain, fog and mist by reversed phase liquid chromatography of the 2,4-dinitrophenylhydrozone derivatives. Int. J. envir. analyt. Chem. 18, 253-266.

Turpin B. J. and Huntzicker J. J. (1991) Secondary formation of organic aerosol in the Los Angeles Basin: a descriptive analysis of organic and elemental carbon concentrations. Atmospheric Environment 25A, 207-215.

Warneck P. (1988) Chemistry of the Natural Atmosphere. Academic Press, San Diego.

Yokouchi Y. and Ambe Y. (1986) Characterization of polar organics in airborne particulate matter. Atmospheric Environment 20, 1727-1734.

Zhou X. and Mopper K. (1990) Measurement of sub-partsper-billion levels of carbonyl compounds in marine air by a simple cartridge trapping procedure followed by liquid chromatography. Envir. Sci. Technol. 24, 1482-1485. 